\title{
The Primary Jurisdiction Two-Step
}

\author{
Bryson Santaguida $\dagger$
}

\section{INTRODUCTION}

The doctrine of primary jurisdiction applies when a claim is originally cognizable in the courts but involves issues that fall within the special competence of an administrative agency. Under the doctrine, a court can stay litigation and refer such issues to the agency for its decision. ${ }^{1}$ Primary jurisdiction is a cousin of better known abstention doctrines that permit (and sometimes require) federal courts to abstain from addressing issues cognizable by state courts or state agencies. $^{2}$ The essential difference between primary jurisdiction and these other forms of abstention is that primary jurisdiction furthers comity between federal courts and federal agencies rather than federal courts and state institutions.

As the Supreme Court has explained, "[n]o fixed formula exists for applying the doctrine of primary jurisdiction." ${ }^{3}$ When a federal district court decides if an agency has primary jurisdiction over an issue, it must ask "whether the reasons for the existence of the doctrine are present and whether the purposes it serves will be aided by its application in the particular litigation." ${ }^{4}$ One thing is certain: every grant of primary jurisdiction requires district courts to first interpret enabling statutes and then exercise judicial discretion. Because the propriety of primary jurisdiction includes legal and discretionary considerations, circuit courts face the difficult task of deciding whether to review primary jurisdiction decisions de novo or for abuse of discretion. Statutory interpretation is a matter of law and therefore reviewed de novo. Decisions that turn on the discretion of a trial court are reviewed for an abuse of discretion.

\footnotetext{
$\dagger$ BA 2004, The University of Texas at Austin; JD 2007, The University of Chicago.

1 See United States $v$ Western Pacific Railroad Co, 352 US 59, $62-65$ (1956) (explaining when primary jurisdiction applies and noting that "in such a case the judicial process is suspended pending referral of such issues to the administrative body for its views"). See generally Louis $L$. Jaffe, Primary Jurisdiction, 77 Harv L Rev 1037 (1964).

2 Primary jurisdiction will be compared more fully with these forms of abstention in Part I.

Western Pacific Railroad, 352 US at 64.

Id.

5 See, for example, Pierce $v$ Underwood, 487 US 552, 559 (1988). See also Steven Alan Childress and Martha S. Davis, Federal Standards of Review 4.01 (Lexis 3d ed 1999).
} 
Circuits currently disagree on how to review primary jurisdiction rulings. Some circuits review de novo, while others review for abuse of discretion. ${ }^{6}$ Both standards lack sufficient precision. Similar to other abstention doctrines, the proper approach is to view primary jurisdiction as a two-step inquiry and review it in a two-tiered fashion. Courts of appeals should review the legal predicate necessary to grant primary jurisdiction de novo and the discretionary component for abuse of discretion.

This Comment explores why circuit courts are split on the standard of review and proposes to resolve the split by offering an alternative to either exclusively de novo review or review for abuse of discretion. Part I provides background on the doctrine of primary jurisdiction and compares it to other doctrines of federal court abstention. Part II analyzes the two competing standards of review and attempts to explain the development of the current split. Part III urges appellate courts to abandon the choice between the de novo and abuse of discretion standards, and suggests reviewing in a two-step manner that parallels the two-step inquiry of district courts.

\section{THE DOCTRINE OF PRIMARY JURISDICTION}

This Part examines the evolution of primary jurisdiction and its role in distributing decisionmaking power between courts and agencies. Primary jurisdiction evolved out of the Supreme Court's recognition that federal agencies are sometimes superior decisionmaking bodies because of their expertise and ability to preserve uniformity within a regulatory scheme. In this way, it furthers the same institutional values as the Chevron doctrine. Under Chevron U.S.A. Inc v $N R D C{ }^{7}$, deference to agency interpretations of statutes is after-thefact. Primary jurisdiction, in contrast, is a form of abstention. ${ }^{8}$ Like other abstention doctrines, it operates by providing before-the-fact deference notwithstanding judicial jurisdiction over a matter. Also like other abstention doctrines, primary jurisdiction requires courts to engage in a two-step analysis.

\footnotetext{
6 See Southern Utah Wilderness Alliance v Bureau of Land Management, 425 F3d 735, 750 (10th Cir 2005) (discussing the circuit split).

7467 US 837 (1984).

8 See David P. Currie, Federal Courts: Cases and Materials 503 (West 4th ed 1990) ("In cases confronting federal courts with issues within the special knowledge of federal administrative agencies, the Supreme Court has developed a doctrine of 'primary jurisdiction,' somewhat analogous to abstention, under which the technical question is referred to the agency for decision."), citing United States v Western Pacific Railroad Co, 352 US 59 (1956).
} 
A. The Development of Modern Primary Jurisdiction

Primary jurisdiction was developed by the Supreme Court over a series of cases primarily involving regulated industries.' Part I.A.1 tracks the development of primary jurisdiction by the Supreme Court. Part I.A.2 explains how the doctrine is applied today.

\section{Historical background.}

The Supreme Court created the doctrine in the landmark case of Texas and Pacific Railway Co v Abilene Cotton Oil Co. ${ }^{10}$ A federal statute provided that common carriers, such as Texas and Pacific, were required "to charge only just and reasonable rates" and submit rate schedules to the Interstate Commerce Commission (ICC). " The statute vested the ICC with the duty of determining whether rates were reasonable. ${ }^{12}$ Additionally, the statute provided " $[t]$ hat any person or persons claiming to be damaged by any common carrier ... may either make complaint to the [Interstate Commerce] Commission ... or may bring suit in his or their own behalf for the recovery ... in any District or Circuit Court of the United States." ${ }^{13}$

During trial, Texas and Pacific relied on the absence of an ICC determination that the rates it charged Abilene Cotton Oil were unreasonable to argue that the court could not rule the rates were unreasonable. ${ }^{14}$ The district court ruled the rates were unreasonable anyway. ${ }^{15}$ On appeal, the Supreme Court held that the ICC alone was competent to decide whether a carrier rate was unreasonable. ${ }^{16}$ The Court concluded that rates "might be found reasonable by the Commission in the first instance and unreasonable by a court acting originally, and thus a conflict would arise." ${ }^{\text {.17 }}$ According to the Court, this conflict could potentially obviate the congressional delegation to the

9 See United States v Philadelphia National Bank, 374 US 321, 353 (1963) ("[Primary jurisdiction] requires judicial abstention in cases where protection of the integrity of a regulatory scheme dictates preliminary resort to the agency which administers the scheme."). See also Childress and Davis, Federal Standards of Review at 14.08 (cited in note 5) (stating that primary jurisdiction "has been longest and most widely applied in the regulated industries").

10204 US 426 (1907).

11 Id at 437-38.

12 Id.

13 Id at 438-39 (quotation marks omitted).

14 Id at $430-31$.

15 See id at 432

16 Id at $440-41$.

17 Id at 441 . The Court also relied in part on the statute's condition that persons pursuing claims "shall not have the right to pursue" a remedy in both the ICC and federal court. See id at 439 . 
ICC to administer the statute with uniformity. Therefore, the matter should have been referred to the ICC. ${ }^{18}$

The Court emphasized agency expertise as a reason for abstention forty-five years later in Far East Conference $v$ United States. ${ }^{19}$ The United States sued the Far East Conference under the Sherman Act to enjoin them from imposing a dual-rate system for steam shipping. The Far East Conference was a voluntary association of steamship companies who agreed to charge each other a discounted shipping rate as long as they never used nonmembers' ships. ${ }^{20}$ Companies "who did not bind themselves by such exclusive patronage contract paid a fixed higher rate." ${ }^{21}$ The Supreme Court held that the Federal Maritime Board would have to address the government's claim that the Conference's policy of charging its members lower rates than nonmembers violated the antitrust laws. ${ }^{2}$ The Court's rationale was that a decision would implicate considerations "generally unfamiliar to a judicial tribunal, but well understood by an administrative body especially trained and experienced in the intricate and technical facts." ${ }^{23}$ The Court noted the complexity of the international shipping industry in requiring the Maritime Board to address the government's claims, but maintained that a court could ultimately resolve the dispute. ${ }^{24}$ Even though regulatory uniformity was not a concern, the Court established that primary jurisdiction can also be appropriate when the expertise of an agency will minimize the risk of judicial error.

2. United States $v$ Western Pacific Railroad $\mathrm{Co}^{25}$ and the modern formulation of primary jurisdiction.

In the pivotal case of Western Pacific Railroad, the Supreme Court synthesized the two considerations driving primary jurisdiction and set out its modern framework. Three railroads sued the United States to

18 Id at 440-41. In a later case, the Court highlighted the importance of the statutory interpretation element of a primary jurisdiction determination more explicitly than it had in Texas and Pacific Railway. See General American Tank Car Corp v El Dorado Terminal Co, 308 US 422,433 (1940) ("When it appeared ... that an administrative problem, committed to the [ICC], was involved, the court should have stayed its hand pending the [ICC's] determination of the lawfulness and reasonableness of the practices under the terms of the Act.").

19342 US 570 (1952).

20 Id at 572.

21 See id at 572

22 Id at 573.

23 Id at 573-74, quoting United States Navigation Co v Cunard Steamship Co, 284 US 474, 485 (1932).

24 See Far East Conference, 342 US at 573-74 (concluding that the Federal Maritime Board "should not be passed over ... even though the facts after they have been appraised by specialized competence serve as a premise for legal consequences to be judicially defined").

25352 US 59 (1956). 
recover the difference between tariff rates actually paid by the United States and those that the railroads alleged were due. ${ }^{26}$ The government argued that the litigation should be stayed to allow the ICC to first address whether the rates requested by the railroads were unreasonable. ${ }^{27}$ The Court of Claims declined to do so and entered summary judgment in favor of the railroads. ${ }^{28}$

The Supreme Court reversed the Court of Claims's refusal to suspend the action. ${ }^{29}$ The Court held that the issues should be referred to the ICC, and, in so doing, it outlined the modern framework of primary jurisdiction:

Primary jurisdiction ... applies where a claim is originally cognizable in the courts, and comes into play whenever enforcement of the claim requires the resolution of issues which, under a regulatory scheme, have been placed within the special competence of an administrative body; in such a case the judicial process is suspended pending referral of such issues to the administrative body for its views. ${ }^{30}$

The Supreme Court recognized that "[n]o fixed formula exists for applying the doctrine of primary jurisdiction." ${ }^{31}$ There are, however, two elements involved in every trial court's grant of primary jurisdiction. First, a court must determine if a statute grants an administrative agency authority over the issues that are potentially the subject of primary jurisdiction. ${ }^{32}$ This first step is a question of statutory interpretation. Second, if the issue is one that the agency has authority to ad-

26 Id at 60

27 Id at $61-62$.

28 Id at 62 .

29 Id at 63.

30 Id at 63-64 (quotation marks omitted). This framework reflects a shift from the view in Texas and Pacific Railway and Far East Conference that the doctrine required exclusive jurisdiction to be vested in an agency. The original and strongest version of primary jurisdiction is more aptly viewed as "exclusive jurisdiction" or part of the "exhaustion" of remedies doctrine. See Western Pacific Railroad, 352 US at 63 ("'Exhaustion' applies where a claim is cognizable in the first instance by an administrative agency alone; judicial interference is withheld until the administrative process has run its course."). Modern primary jurisdiction is applied in a "weaker sense." In re StarNet, Inc, 355 F3d 634, 639 (7th Cir 2004) ("This is not to say that the agency has exclusive jurisdiction, the original and strongest meaning of 'primary jurisdiction.' We use the phrase in its weaker sense, as a doctrine that allows a court to refer an issue to an agency that knows more about the issue.") (citation omitted). See also Reiter v Cooper, 507 US 258, 268 (1993) (stating that the conflation of exhaustion and primary jurisdiction "reflects a mistaken understanding of primary jurisdiction, which is a doctrine specifically applicable to claims properly cognizable in court that contain some issue within the special competence of an administrative agency").

31 Western Pacific Railroad, 352 US at 64.

32 Id (explaining that primary jurisdiction "comes into play whenever enforcement of the claim requires the resolution of issues which, under a regulatory scheme, have been placed within the special competence of an administrative body"). 
dress, then a court must decide "whether the purposes [the doctrine] serves will be aided by its application in the particular litigation.". This second step is a matter of discretion.

Under Western Pacific Railroad, courts consider two factors when deciding whether to exercise their discretion at the second step of the analysis. The first is whether giving an agency the initial opportunity to decide an issue will foster "the desirable uniformity which would obtain if initially a specialized agency passed on certain ... questions.." ${ }^{34}$ The second is whether "the expert and specialized knowledge of the [agency]" will assist in the proper resolution of an issue.

In evaluating the second question, courts often consider three factors. First, they examine whether the issues involve matters that extend "beyond the conventional experiences of judges." ${ }^{36}$ For example, in National Communications Association, Inc v AT\& $T$, the Second Circuit concluded that the question of whether a company qualified for a particular tariff, which turned on whether it had paid bills on time, was a simple factual question that did not "present any issues involving intricate interpretations or applications of tariffs that might need the FCC's technical or policy expertise." ${ }^{38}$ The court noted that "[s]tatutory reasonableness of a tariff should, of course, be reviewed by an agency because it is an abstract quality represented by an area rather than a pinpoint." ${ }^{39}$

Second, courts consider "whether there exists a substantial danger of inconsistent rulings." ${ }^{40}$ This factor often depends on a court's view of whether there are issues beyond the conventional knowledge of judges. Judges' determinations of issues within their conventional knowledge are less likely to be deemed incorrect by an expert agency. In National Communications Association, the Second Circuit determined there was no risk of inconsistent rulings because the district court would not be required to interpret any tariff provisions of the relevant statute nor address the reasonableness of any tariff provisions. ${ }^{41}$ Because courts do not develop narrow expertise, judicial inter-

33 Id

34 Id.

35 Id.

36 National Communications Association, Inc v AT\&T, 46 F3d 220, 222-23 (2d Cir 1995) (describing this inquiry as "whether the question at issue is within the conventional experience of judges or whether it involves technical or policy considerations within the agency's particular field of expertise"), quoting Far East Conference, 342 US at 574.

3746 F3d 220 (2d Cir 1995).

38 Id at 223.

39 Id (quotation marks omitted).

40 Id at 222.

41 Id at 223-25. 
pretation of tariff provisions would likely differ from that of an agency with expert knowledge in the relevant industry.

Finally, courts look to "whether a prior application to the agency has been made." ${ }^{42}$ They do this because reference to an agency can substantially delay litigation that may need quick resolution. ${ }^{43}$ The National Communications Association court agreed with the petitioner's conclusion that "the district court failed to recognize the need to resolve this dispute as quickly and fairly as possible.", The Second Circuit concluded that "a potential delay of even two years more than outweighs any benefit that might be achieved by having the FCC resolve this relatively simple factual dispute." ${ }^{45}$

An important procedural aspect of primary jurisdiction is that when a court applies the doctrine, the "[r]eferral ... to the administrative agency does not deprive the court of jurisdiction." ${ }^{46}$ Instead, the court maintains jurisdiction and proceedings are usually stayed. ${ }^{47} \mathrm{Pri}-$ mary jurisdiction is not, therefore, jurisdictional in a strict sense. It merely relates to whether a court will exercise its jurisdiction. ${ }^{48}$ If pri-

42 Id at 222. Courts often ask a fourth question - "whether the question at issue is particularly within the agency's discretion"-even though it merely adds a semantic variant to the statutory interpretation element of a primary jurisdiction determination. Id.

43 See id at 225. In National Communications Association, "the parties estimated that the delay resulting from referring [the] case to the FCC would be from two to five years." Id.

44 Id. Neither party had initiated proceedings with the FCC. Id at 222.

45 Id at 225.

46 Reiter, 507 US at 268.

47 If the court decides "the parties would not be unfairly disadvantaged," it is permissible for a court "to dismiss the case without prejudice." Id at 268-69.

48 Sometimes the enabling statute will provide a mechanism whereby a court can demand or request an agency's view. More often, the "referral" is "left to the adversary system"-that is, the court stays proceedings to allow one of the parties to file with the agency. Id at $268 \mathrm{n} 3$. It has been pointed out that "presently [primary jurisdiction] is used to refer to both issues that must be initially decided by the administrative agency and issues that may be initially decided by the administrative agency." Childress and Davis, Federal Standards of Review at 14.08 (cited in note 5). But this view ignores the discrete adjudicative steps discussed above. Issues that must be decided by an administrative agency do not implicate the judicial discretion exercised in step two. If the court must abstain after determining Congress granted an agency sole authority to address the issues as an initial matter, it is properly considered exhaustion. Reiter, 507 US at 268-69 (contrasting exhaustion with the "referral" process of primary jurisdiction). One commentator has noted that primary jurisdiction "shares with the requirement that administrative remedies be exhausted the purpose of obtaining the views of an agency on matters within its competence." Currie, Federal Courts 503 n 3 (cited in note 8). But, unlike exhaustion, agency action is not required before a federal court can address the issues subject to primary jurisdiction. Id. The Supreme Court expressly distinguished such a situation from primary jurisdiction in Western Pacific Railroad and Reiter. See Reiter, 507 US at 268-69; Western Pacific Railroad, 352 US at 63. As discussed in Part I.B.1, the requisite nature of Younger and Thibodaux abstention distinguishes them from primary jurisdiction in the same way. 
mary jurisdiction was strictly jurisdictional, it would be purely a matter of law and reviewed de novo. ${ }^{49}$

\section{B. The Role of Primary Jurisdiction}

Primary jurisdiction plays an important institutional role by properly allocating decisionmaking power between courts and agencies. It can also have a significant impact in individual cases. Part I.B.1 examines primary jurisdiction's importance in administrative law by comparing it to the Chevron doctrine and other forms of abstention. Part I.B.2 examines the strategic importance of primary jurisdiction in individual cases.

\section{Institutional role.}

As the foregoing background suggests, primary jurisdiction "is concerned with promoting proper relationships between the courts and administrative agencies." "represents a determination that administrative agencies are better equipped than the courts to handle particular questions, and that referral of appropriate questions to an agency ensures desirable uniformity of results."

Primary jurisdiction is based on the same rationale as the Chevron doctrine. In Chevron, the Supreme Court addressed the proper framework for deference to administrative agencies on issues of statu-

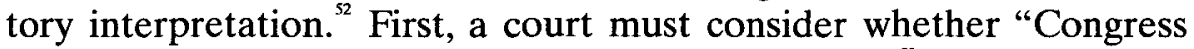
has directly spoken to the precise question at issue." If If the statute is clear, "that is the end of the matter" because the agency, like the court, "must give effect to the unambiguously expressed intent of Congress." If the statute is ambiguous, step two is to consider "whether

49 See In re Special Grand Jury 89-2, 450 F3d 1159, 1170 (10th Cir 2006) ("We review jurisdictional questions de novo.").

50 Western Pacific Railroad, 352 US at 63. See also Reiter, 507 US at 268 ("[Primary jurisdiction] is a doctrine specifically applicable to claims properly cognizable in court that contain some issue within the special competence of an administrative agency.").

51 Williams Pipe Line Co v Empire Gas Corp, 76 F3d 1491, 1496 (10th Cir 1996). See also Pharmaceutical Research and Manufacturers of America v Walsh, 538 US 644, 673 (2003) ("[Primary jurisdiction] seeks to produce better informed and uniform legal rulings by allowing courts to take advantage of an agency's specialized knowledge, expertise, and central position within a regulatory regime.").

52 See 467 US at $842-43$.

53 Id at 842 .

54 Id at 842-43. 
the agency's answer is based on a permissible construction of the statute."

In some ways, the Chevron doctrine mirrors primary jurisdiction. Both first steps are a pure question of legal interpretation in which judges apply the full panoply of interpretive tools. Similarly, both second steps provide an opportunity for courts to defer to agencies. Chevron creates after-the-fact deference by upholding any agency interpretation that is "permissible." Primary jurisdiction creates a before-the-fact opportunity for an agency to decide certain issues. Those decisions are then reviewed with varying degrees of deference. ${ }^{56} \mathrm{Op}$ erationally, the parallel is limited. Chevron is after-the-fact review of agency interpretations, and both steps relate to statutory interpretation. "7 In the broader administrative context, however, the values underlying Chevron illustrate why primary jurisdiction is also important.

Chevron deference has been questioned by academics on practical and constitutional grounds, ${ }^{58}$ yet it remains vital. ${ }^{59}$ There are five common justifications for Chevron ${ }^{60}$ The first is political responsiveness and accountability. Administration of a regulatory regime inevitably involves "the essentially legislative process of adjusting the competing claims of various private interests affected by agency policy." Deference to agencies allows "the citizenry, through the mechanism of

55 Id at 843. Courts' fidelity to Chevron is often called into question. Consider generally, for example, Adrian Vermeule, Mead in the Trenches, 71 Geo Wash L Rev 347 (2003) (analyzing the legal repercussions of United States v Mead, 533 US 218 (2001), and observing that Mead reversed the "key innovation of Chevron" - "a global interpretive presumption"); Robert A. Anthony, Keeping Chevron Pure, 5 Green Bag 2d 371 (2002) (arguing that the decision in Barnhart $v$ Walton, 535 US 212 (2002), threatens to "cut [the entire Chevron enterprise] loose from its delegation/force-of-law theoretical foundations ... [and cause Chevron to] lose its practical virtue of furnishing reasonable certainty in most cases about when the agencies' interpretations will stand"). Regardless of Chevron's doctrinal purity, it is the values underlying Chevron that illustrate the role of primary jurisdiction in the broader administrative context.

56 See Part I.B.2.

57 Some have noted that agency interpretations can present mixed questions of fact and policy. See, for example, Cass R. Sunstein, Constitutionalism after the New Deal, 101 Harv L Rev 421, 466 (1987) (arguing that the case for deference is strongest "when the issue involves questions of fact and policy - a 'mixed' question - and when resolution thus depends on extralegal concerns").

58 See, for example, Clark Byse, Judicial Review of Administrative Interpretation of Statutes: An Analysis of Chevron's Step Two, 2 Admin L J 255, 260-61 (1988) (discussing two angles of criticism-that the Chevron rule is "too simple and indiscriminate" and that it "violates separation of powers").

59 See Stephen G. Breyer, et al, Administrative Law and Regulatory Policy: Problems, Text, and Cases 247 (Aspen 6th ed 2006) ("Chevron has become one of the most cited cases in all of American law."). See also National Cable and Telecommunications Association v Brand X Internet Services, 545 US 967, 981 (2005) (stating that "[a]s we have in the past, we apply the Chevron framework").

60 Breyer, et al, Administrative Law and Regulatory Policy at 257-60 (cited in note 59).

61 Richard B. Stewart, The Reformation of American Administrative Law, 88 Harv L Rev 1667,1683 (1975) (discussing the tension between administrative discretion and judicial review). 
electing a President, to effect a change in governmental policies without incurring the high transaction costs of securing enactment of specific legislation."

A second justification is comparative competence. Agencies are experts on the subject matter of statutes they administer. Agencies hire technical experts, are repeat players on their policy subject matter, and maintain relations with relevant stakeholders. ${ }^{63}$ Article III courts are generalists. Because they lack the institutional expertise of agencies they are ill-equipped to understand certain issues and unable to properly balance relevant considerations. ${ }^{64}$

A third justification for Chevron is efficiency. The Chevron doctrine gives agencies more interpretive authority. This increased authority channels high-quality, aggressive argumentation to agency proceedings. ${ }^{65}$ Moreover, agencies are encouraged to take responsibility for resolving issues and improving their procedures. ${ }^{66}$ Therefore, litigants will be less inclined to seek review of agency determinations in light of the increased investment up front (by the agency and the parties) and decreased expectations of a favorable outcome on review. ${ }^{6}$ Even though judges stay proceedings under primary jurisdiction, there are potential efficiency gains. Parties are encouraged to invest more. in resolving disputes via agencies beforehand. ${ }^{68}$ Agencies, in turn, will have the same incentive to take responsibility and improve their ability to address parties' issues.

A fourth justification is national uniformity. The centralization of agency decisionmaking relative to federal courts allows uniform policymaking. ${ }^{69}$ Chevron deference and primary jurisdiction are methods

62 Byse, 2 Admin $\mathrm{L} \mathrm{J}$ at 257 (cited in note 58).

63 Id at 258.

64 See Colin S. Diver, Statutory Interpretation in the Administrative State, $133 \mathrm{U}$ Pa L Rev $549,574-82$ (1985) (comparing the knowledge, process, and motives of courts and agencies in interpreting statutes and concluding agencies have a strong comparative advantage in interpreting the statutes they enforce). See also, for example, Access Telecommunications $v$ Southwestern Bell Telephone Co, 137 F3d 605, 609 (8th Cir 1998) ("The FCC has far more expertise than the courts on matters such as circuit designs, signal transmissions, noise attenuation, and echo return loss. Thus, the need to draw upon the FCC's expertise and experience is present here.").

65 Kenneth W. Starr, Judicial Review in the Post-Chevron Era, 3 Yale J Reg 283, 311 (1986) (asserting that under Chevron, "litigants will have an increased incentive to make their best arguments, clearly and aggressively, before the agency rather than waiting for the main event at the courthouse").

66 Id.

67 Byse, 2 Admin L J at 258 (cited in note 58).

68 Consider, for example, National Communications Association, 46 F3d at 222 (noting that agency proceedings already underway favor a grant of primary jurisdiction at step two).

69 See Byse, 2 Admin L J at 259 (cited in note 58) ("The more independent the scope of review [of administrative agencies,] the greater likelihood of differing judicial responses in these various courts."). 
of "allocating functions between agencies and courts so as to reduce the chance that the lower courts will introduce undesirable geographical diversity into national law, thus reducing the number of occasions when the court must intervene." ${ }^{70}$

Finally, a common justification for Chevron deference, which also highlights the institutional role of primary jurisdiction, is agency flexibility. Agencies can react to technological or political changes more easily than can courts. ${ }^{71}$ Courts are less flexible. Their influence over regulatory regimes is exercised almost exclusively through deciding cases. In addition, courts' flexibility is limited by the binding presence of precedent. They are not only slow, but often unwilling to respond to "scientific, industrial, or other developments."

Chevron and primary jurisdiction serve the same goals by shifting decisionmaking power. The authority of courts and agencies "interact[s] over a broad range of situations." In these situations, primary jurisdiction harmonizes the comparative advantages of agency decisionmaking with judicial jurisdiction by providing a framework for determining if an agency's view will aid in resolving the overall dispute. Primary jurisdiction is critical because many disputes in which agency involvement would further proper resolution "cannot be resolved by the single abstraction of administrative expertness.",

A complete understanding of primary jurisdiction also requires comparing it to other forms of abstention. The theme that ties Chevron deference and primary jurisdiction together-because a court can do something does not mean it ought to ${ }^{75}$-makes both similar to established abstention doctrines that seek to promote comity between

70 Peter L. Strauss, One Hundred Fifty Cases per Year: Some Implications of the Supreme Court's Limited Resources for Judicial Review of Agency Action, 87 Colum L Rev 1093, 1117 (1987).

71 See Byse, 2 Admin L J at 259 (cited in note 58) (asserting that while it is unlikely that a court "will later change its interpretive mind," an agency is more likely to adapt to changing circumstances).

72 Id.

73 Jaffe, 77 Harv L Rev at 1038 (cited in note 1) (discussing various contexts in which causes of action and remedies involve issues within the jurisdiction of courts and agencies).

74 Id at 1041. See also, for example, Williams Pipe Line, 76 F3d at 1496 ("Thus, while the court is ultimately the appropriate body to declare a tariff practice void as against public policy, it should nonetheless refer the initial determination to the regulatory agency where it may benefit from the agency's expertise and insight, and to ensure uniformity.").

75 Note that Chevron is a judicially created doctrine. See Elliot Greenfield, $A$ Lenity Exception to Chevron Deference, 58 Baylor L Rev 1, 23 (2006) ("Although the Court has made clear that its rule of mandatory deference rests on congressional intent, the underlying presumption of delegation is itself a judicial creation."); Maureen B. Callahan, Must Federal Courts Defer to Agency Interpretations of Statutes?: A New Doctrinal Basis for Chevron U.S.A. v. Natural Resources Defense Council, 1991 Wis L Rev 1275, 1289 (1991) (noting that "no convincing indication that the Chevron result was compelled by external forces exists"). 
federal courts and state institutions. ${ }^{76}$ Chevron, primary jurisdiction, and abstention reflect a form of judicial humility. Each is a method of deferring to a more appropriate decisionmaker. Primary jurisdiction shares the underlying values of Chevron and both doctrines defer to federal agencies. But it is more analogous to other abstention doctrines in how it is applied-abstention and primary jurisdiction are ex ante methods of shifting authority.

There are several well-known forms of abstention. Each calls for a federal court to abstain from exercising jurisdiction for a different reason." Burford abstention is appropriate when a federal court should defer to complex state administrative procedures. ${ }^{78}$ The underlying goal of Burford abstention is preventing federal courts from disrupting important state regulatory schemes when they are "asked to intervene in resolving [an] essentially local problem." "79 Much like primary jurisdiction, Burford abstention is justified by a legislative decision that an administrative agency is better suited to address certain issues. However, under Burford, state lawmakers provide an agency with the power to adjudicate certain disputes or promulgate certain rules, whereas under primary jurisdiction, federal lawmakers make that call.

Burford is similar to primary jurisdiction in that the Supreme Court "has not provided a formulaic test for determining when dismissal under Burford is appropriate." ${ }^{\text {"Bo }}$ Burford abstention also involves a two-step inquiry. ${ }^{81}$ Just like primary jurisdiction, the first step in deciding whether to abstain is a legal inquiry. A court must initially

76 See Callahan, 1991 Wis L Rev at 1289 (cited in note 75) ("Chevron is best understood as having established what is essentially a rule of abstention in favor of another governmental decisionmaker.").

77 Abstention doctrines are typically referred to by the name of the Supreme Court case that pioneered the doctrine. For example, Pullman abstention refers to abstention premised on Railroad Commission of Texas v Pullman Co, 312 US 496 (1941), and its progeny.

78 See Burford v Sun Oil Co, 319 US 315 (1943).

79 Alabama Public Service Commission v Southern Railway Co, 341 US 341, 347 (1951). See also American Disposal Services, Inc v O'Brien, 839 F2d 84, 87 (2d Cir 1988) (stating that the goal of Burford abstention is to "avoid resolving difficult state law issues involving important public policies or avoid interfering with state efforts to maintain a coherent policy in an area of comprehensive regulation or administration").

80 City of Tucson v U.S. West Communications, Inc, 284 F3d 1128, 1133 (9th Cir 2002), quoting Quackenbush v Allstate Insurance Co, 517 US 706, 727-28 (1996). Burford abstention differs from primary jurisdiction, and other forms of abstention, in that it "does not merely 'postpone' federal court jurisdiction; it completely displaces federal court review." Erwin Chemerinsky, Federal Jurisdiction 781 (Aspen 4th ed 2003).

81 This two-step analysis has led to some uncertainty in lower courts. See Chemerinsky, Federal Jurisdiction at 780-81 (cited in note 80) (discussing the variety of approaches taken by lower courts). 
ask whether the requirements for abstention exist. ${ }^{82}$ A judge who has determined that the legal predicate for abstention exists must then determine whether, "as a matter of sound equitable discretion," the court should abstain."

Other forms of abstention share this two-step quality. Colorado River abstention allows a federal court to abstain from exercising jurisdiction and defer to a state court's concurrent jurisdiction when a parallel state action is pending. ${ }^{84}$ This form of abstention is "one resting ... on considerations of ... conservation of judicial resources and comprehensive disposition of litigation." trict court under Colorado River is whether "exceptional circumstances" sufficient for abstention exist - a legal question. ${ }^{86}$ If the district court determines that the conditions for allowing abstention exist, the district court must exercise its discretion to determine whether abstention is appropriate in the particular case.

82 Circuit courts vary how they frame this determination. See, for example, U.S. West Communications, 284 F3d at 1133 (requiring the district court to determine that "the state has chosen to concentrate suits challenging the actions of the agency involved," that "federal issues could not be separated easily from complex state law issues with respect to which state courts might have special competence," and that "federal review might disrupt state efforts to establish a coherent policy"); Bethphage Lutheran Service, Inc v Weicker, 965 F2d 1239, 1243-45 (2d Cir 1992) (considering "the degree of specificity of the state regulatory scheme, the necessity of discretionary interpretation of state statutes, [ ] whether the subject matter of the litigation is traditionally one of state concern," and whether the state has created a centralized system of review allowing the agency to acquire specialized knowledge).

83 Burford, 319 US at 318. See also U.S. West Communications, 284 F3d at 1132 (noting that district courts should abstain if the case involves complex and important questions of state law, or if federal intervention would disrupt state efforts to establish coherent rules and policies); Bethphage, 965 F2d at 1244-45.

84 See Colorado River Water Conservation District v United States, 424 US 800, 817 (1976) ("[T]here are principles ... which govern in situations involving the contemporaneous exercise of concurrent jurisdictions, either by federal courts or by state and federal courts. These principles rest on considerations of wise judicial administration, giving regard to conservation of judicial resources and comprehensive disposition of litigation.") (quotation marks omitted). See also Rosser v Chrysler Corp, 864 F2d 1299, 1306 (7th Cir 1988) ("Under the rule of [Colorado River], when the proper exceptional circumstances exist, a federal court can abstain from exercising its jurisdiction and defer to the concurrent jurisdiction of a state court.").

85 Moses H. Cone Memorial Hospital v Mercury Construction Corp, 460 US 1, 14-15 (1983) (quotation marks omitted).

86 Rosser, $864 \mathrm{~F} 2 \mathrm{~d}$ at 1306. The Supreme Court has identified four factors to consider: (1) "inconvenience of the federal forum"; (2) "[t]he desirability of avoiding piecemeal litigation"; (3) "[t]he order in which jurisdiction was obtained by the concurrent forums"; and (4) "the fact that federal law provides the rule of decision on the merits." Mercury Construction, 460 US at 15, 23.

87 See, for example, Arizona v San Carlos Apache Tribe of Arizona, 463 US 545, 569 (1983) (concluding that "the District Courts were correct in deferring to the state proceedings"); Holder $v$ Holder, 305 F3d 854, 863 (9th Cir 2002) (concluding that "the district court erred in staying proceedings"); United States Fidelity \& Guaranty Co v Murphy Oil USA, Inc, 21 F3d 259, 263 (8th Cir 1994) (upholding the district court's decision to stay federal court proceedings). 
Pullman abstention also involves a two-step approach. ${ }^{88}$ Pullman abstention allows a federal court to suspend proceedings when it is confronted with a dispute where unsettled state law implicates a federal constitutional question that could be avoided or narrowed by resolution of the state-law question. ${ }^{89}$ Like Burford and Colorado River abstention, the decision to abstain begins with a legal determination. A district court must decide whether there are "[u]ncertain issues of state law underlying the federal constitutional claims brought in federal court" and "[s]tate law issues amenable to a state court interpretation that would obviate the need for, or substantially narrow, the scope of adjudication of the constitutional claims." If both "special circumstances" exist, then the district court must "make a discretionary determination as to whether abstention is in fact appropriate under the circumstances of the particular case."

Not all forms of abstention consist of two steps. Two abstention doctrines require a purely legal inquiry. First, Thibodaux abstention allows a federal court to stay proceedings in favor of state-court litigation when the issues presented are of a "special nature" to the state."

88 See Pullman, 312 US at 499-501.
89 See id at 500:

The reign of law is hardly promoted if an unnecessary ruling of a federal court is thus supplanted by a controlling decision of a state court. The resources of equity are equal to an adjustment that will avoid the waste of a tentative decision as well as the friction of a premature constitutional adjudication.

90 Chez Sez III Corp v Township of Union, 945 F2d 628, 631 (3d Cir 1991).

91 Id. This discretionary component involves consideration of "whether an erroneous decision of state law by the federal court would disrupt important state policies." If state policies would be in jeopardy, a court must consider whether the other factors make the case suitable for resolution in federal court. See id at $631,633$.

92 See Louisiana Power \& Light Co v City of Thibodaux, 360 US 25, 29 (1959). In Thibodaux, there was uncertainty about the reach of the state's eminent domain power due to tension between "an old uninterpreted statute" and a pronouncement by the Attorney General of Louisiana. Id at 30 . The Supreme Court ruled that the importance of defining Louisiana's eminent domain power favored abstention despite the usual rule that unclear state law does not eviscerate jurisdiction. See id at 28. Though Pullman recommends staying judicial proceedings when unsettled state law intersects with federal constitutional questions, Meredith $v$ Winter Haven, 320 US 228 (1943), held that federal courts cannot relinquish jurisdiction "merely because ... [state] law is uncertain or difficult to determine," id at 236. Lower courts have been divided on how to determine when the state issues presented have the requisite "special nature." See, for example, Miller-Davis Co v Illinois State Toll Highway Authority, 567 F2d 323, 326-27 (7th Cir 1977); Sayers v Forsyth Building Corp, 417 F2d 65, 72-74 (5th Cir 1969); United Services Life Insurance Co v Delaney, 328 F2d 483, 484 (5th Cir 1964). See also Chemerinsky, Federal Jurisdiction at 779 (cited in note 80 ) (discussing the debate over whether abstention is appropriate in diversity cases). The Supreme Court has upheld abstention under Thibodaux only once. See Kaiser Steel Corp v W.S. Ranch Co, 391 US 593, 594 (1968) (per curiam). See also Chemerinsky, Federal Jurisdiction at 778 (cited in note 80 ). 
If the necessary legal conditions for Thibodaux abstention exist, abstention is requisite.

Younger abstention differs from primary jurisdiction in the same way as Thibodaux abstention. ${ }^{94}$ Younger abstention precludes federal courts from enjoining pending state court proceedings (that is, requires abstention), especially if important state issues are at stake. ${ }^{95}$ The criteria for determining whether abstention is proper are varied and difficult to assess. ${ }^{\circ}$ Whether Younger abstention is appropriate, however, involves a single "essentially legal determination of whether the requirements for abstention have been met."

Each abstention doctrine has a different flavor. Yet they "uniformly reflect a desire to allow state courts to decide certain matters instead of federal courts." ${ }^{\text {,8 }}$ Like primary jurisdiction and Chevron, abstention involves self-imposed limits on federal courts' exercise of jurisdiction. ${ }^{99}$ The difference between the principles of abstention, on one hand, and Chevron and primary jurisdiction, on the other, is the target of deference. Chevron and primary jurisdiction allow shifts of federal judicial authority to federal administrative agencies. Other abstention doctrines shift power from federal courts to state institutions, and do so in a way that closely resembles primary jurisdiction.

\section{Primary jurisdiction in individual cases.}

Litigants have an immediate interest in whether a court decides to grant primary jurisdiction to an agency. First, one of the parties in the action may be the agency to which the court will defer. For exam-

93 See Kaiser Steel, 391 US at 594 ("Sound judicial administration requires that the parties in this case be given the benefit of the same rule of law which will apply to all other businesses and landowners.") (emphasis added).

94 See Younger v Harris, 401 US 37, 41 (1971).

95 See Middlesex County Ethics Committee v Garden State Bar Association, 457 US 423, 432 (1982). Abstention can apply in a variety of contexts. See, for example, Pennzoil Co v Texaco Inc, 481 US 1, 10-14 (1987) (holding Younger abstention can apply to the judgment phase of state civil proceedings); Huffman v Pursue Ltd, 420 US 592, 603-04 (1975) (holding Younger abstention can apply when there are state civil proceedings); Younger, 401 US at 41 (holding abstention should apply when there are state criminal proceedings).

96 See Chemerinsky, Federal Jurisdiction at 806-36 (cited in note 80).

97 Brooks v New Hampshire Supreme Court, 80 F3d 633, 637 (1st Cir 1996). The principle underlying Younger abstention is that "the National Government will fare best if the States and their institutions are left free to perform their separate functions in their separate ways." Huffman, 420 US at 601, quoting Younger, 401 US at 44. See also Champion International Corp $v$ Brown, 731 F2d 1406, 1408 (9th Cir 1984) ("That policy rests on notions of comity and respect for state functions and was born of the concern that federal court injunctions might unduly hamper state criminal prosecutions.").

98 Chemerinsky, Federal Jurisdiction at 762 (cited in note 80).

99 See Michael Wells, Why Professor Redish is Wrong about Abstention, 19 Ga L Rev 1097, 1097 (1985). 
ple, in Southern Utah Wilderness Alliance v Bureau of Land Management ${ }^{100}$ several counties were in litigation over work the counties had performed on primitive roads that were managed by the Bureau of Land Management (BLM). ${ }^{101}$ The overarching issue was whether the counties could properly claim the roads as rights of way under a federal statute. ${ }^{102}$ The relevant statute stated that certain rights of way that existed prior to October 1976 "would continue in effect." ${ }^{103}$ Determining which rights of way qualify under this statute was difficult because no administrative formalities were instituted to keep track of such matters prior to enactment. ${ }^{104}$ A dispute arose between the Southern Utah Wilderness Alliance and a number of counties over road construction performed by the counties. ${ }^{105}$ The BLM refused to take action as requested by the Alliance, and the Alliance brought suit in federal court to determine if the road construction was properly taking place on rights of way saved by the statute. ${ }^{106}$ The district court, relying on circuit precedent that allowed the BLM to perform an initial round of adjudication over rights of way issues under the statute, stayed proceedings and referred the issue to the BLM. ${ }^{107}$ From the counties' perspective, the district court vested their opposing party with primary jurisdiction over the dispute.

Second, courts review agency determinations deferentially. When a district court grants primary jurisdiction and the agency subsequently issues a ruling, the party prevailing in the administrative ruling will often file a motion to have the administrative ruling enforced by the district court. ${ }^{108}$ An agency's ruling will be subject to review under the appropriate standard of the Administrative Procedure Act. ${ }^{109}$

100425 F3d 735 (10th Cir 2005).

101 See id at $740-43$.

102 See id at $741-42$.

103 See id at 741.

104 See id (noting that the statute required "no entry, no application, no license, no patent, and no deed on the federal side" and "no formal act of public acceptance on the part of the states or localities in whom the right was vested").

105 See id at 742 .

106 See id.

107 See id at 743.

108 See, for example, id (discussing the procedural history).

109 See id at 743-44 (discussing the district court's review of the BLM's rulings under the "arbitrary and capricious" standard of 5 USC $\S 706(2)(A))$. See also 5 USC $\S 706(2000)$. In some instances, a district court will stay proceedings merely to allow the agency to take a position on the issue. Such a stay is not an exercise of primary jurisdiction, and the district court may review the agencies finding de novo. Southern Utah, 425 F3d at 743-44. 
In some instances, the statute that vests the agency with the authority will determine the standard of review. ${ }^{110}$

Regardless of the standard, the varying degrees of deference that district courts apply can exacerbate the concern of litigants because, depending on the enabling statute, an agency may not allow one or both of the parties to participate in its proceedings." adjudication before an agency prior to trial court proceedings increases litigation costs. ${ }^{112}$

\section{CONFUSION AMONG THE CIRCUIT COURTS}

Currently, circuit courts "are split over the standard of review of decisions whether to recognize the primary jurisdiction of an administrative agency." ${ }^{13}$ Some circuits have adopted a de novo standard, while others review for an abuse of discretion. Neither approach is correct. Each results in a mismatch between the chosen standard and one of the elements of a primary jurisdiction decision. This mismatch occurs because the two steps present different kinds of questions-one legal and one discretionary. This Part will briefly examine the alignment of the circuit split. Then it will explore the mechanics of the standard-ofreview mismatch and explain the development of the current split.

\section{A. The Circuit Split}

1. The abuse of discretion camp.

The Third, Fourth, Fifth, Tenth, and D.C. Circuits review primary jurisdiction decisions for abuse of discretion. ${ }^{114}$ However, they have not fully explained why they do so. The Third Circuit, in In re Lower Lake Erie Iron Ore Antitrust Litigation, ${ }^{115}$ suggested that it reviewed for abuse of discretion because a primary jurisdiction ruling made by a lower court is a prudential decision and "despite what the term may imply, does not speak to the jurisdictional power of the federal

110 See, for example, Port of Boston Marine Terminal Association v Rederiaktiebolaget Transatlantic, 400 US 62, 69 (1970) (stating that the Administrative Orders Review Act explicitly precluded the district court from reviewing orders of the Federal Maritime Commission).

111 See, for example, Ricci $v$ Chicago Mercantile Exchange, 409 US 289, 310-11 (1973) (Marshall dissenting) (noting that the Commodity Exchange Commission was not required by statute to allow the petitioner to participate in the agency's proceedings).

112 See Southern Utah, 425 F3d at 742-44 (discussing the lengthy procedural history).

113 Id at 750.

114 See Southern Utah, 425 F3d at 750 (10th Cir); National Telephone Cooperative Association v Exxon Mobil Corp, 244 F3d 153, 156 (DC Cir 2001); Environmental Technology Council v Sierra Club, 98 F3d 774, 789 (4th Cir 1996); In re Lower Lake Erie Iron Ore Antitrust Litigation, 998 F2d 1144, 1162 (3d Cir 1993); Marshall v El Paso Natural Gas Co, 874 F2d 1373, 1377 (10th Cir 1989); Wagner \& Brown v ANR Pipeline Co, 837 F2d 199, 200 (5th Cir 1988).

115998 F2d 1144 (3d Cir 1993). 
courts." ${ }^{116}$ Under this view, the abuse of discretion standard is appropriate because primary jurisdiction determinations are not determinations about whether the court has the authority to decide the issue. Most other circuits review for abuse of discretion without any explanation. ${ }^{11}$

\section{The de novo camp.}

The First, Second, Eighth, and Ninth Circuits review decisions regarding primary jurisdiction de novo. ${ }^{118}$ They also provide little explanation to support their choice of standard of review. Despite the Second Circuit's prior holding in Goya Foods, Inc v Tropicana Products, Inc, ${ }^{119}$ which implied the standard of review for reviewing agencies is abuse of discretion, ${ }^{120}$ the court simply concluded "the standard of review is essentially de novo" in National Communications Association. ${ }^{12}$

In International Brotherhood of Teamsters v American Delivery Service $C o$, Inc, ${ }^{122}$ the Ninth Circuit reviewed de novo the district court's decision not to grant primary jurisdiction to the National Labor Relations Board (NLRB). ${ }^{123}$ Confusingly, the court relied on the notion that the district court's denial was a "jurisdictional finding." This proposition is an odd basis for establishing a de novo standard because primary jurisdiction is not jurisdictional in a strict sense. ${ }^{125}$

The First Circuit, in Newspaper Guild of Salem v Ottaway Newspapers, Inc, ${ }^{126}$ also failed to provide a rationale for de novo review. The court merely cited the Ninth Circuit's decision in International Brotherhood of Teamsters. ${ }^{127}$ The Eighth Circuit, in Access Telecommunica-

116 Id at 1162.

117 See, for example, National Telephone Cooperative Association, 244 F3d at 156 (stating merely that "[w]e review ... only for abuse of discretion"), citing Environmental Technology Council, 98 F3d at 789; Brumark Corp v Samson Resources Corp, 57 F3d 941, 947-48 (10th Cir 1995).

118 See Access Telecommunications v Southwestern Bell Telephone Co, 137 F3d 605, 608 (8th Cir 1998) (reviewing de novo without deciding the question because both parties assumed that standard in their briefs); Newspaper Guild of Salem v Ottaway Newspapers, Inc, 79 F3d 1273, 1283 (1st Cir 1996); International Brotherhood of Teamsters v American Delivery Service Co, Inc, 50 F3d 770, 773 (9th Cir 1995); National Communications Association, 46 F3d at 222 (2d Cir).

119846 F2d 848 (2d Cir 1988).

120 Id at 854 (concluding that "the District Judge applied an incorrect legal standard and thereby exceeded his discretion"). Although Goya Foods had a different procedural posture it concerned issues similar to a question of the propriety of primary jurisdiction.

$12146 \mathrm{~F} 3 \mathrm{~d}$ at 222.

12250 F3d 770 (9th Cir 1995).

123 Id at 773.

124 Id ("We review de novo the District Court's jurisdictional finding that the Union's fraud and misrepresentation claims are ... not within the primary jurisdiction of the NLRB.").

125 See Part I.A.

12679 F3d 1273 (1st Cir 1996).

127 See id at 1283. 
tions $v$ Southwestern Bell Telephone Co, ${ }^{128}$ reviewed de novo because both parties briefed their arguments on the presumption that primary jurisdiction issues are reviewed de novo. ${ }^{129}$

\section{B. The Standard-of-Review Mismatch}

When courts review primary jurisdiction determinations de novo, they review the trial court's statutory interpretation and discretionary decision under the same standard. De novo review is the standard normally applied to lower court decisions of statutory interpretation. ${ }^{13}$ Discretionary matters, however, are normally reviewed for an abuse of discretion. ${ }^{131}$ As one commentator noted, applying de novo review to both elements of a primary jurisdiction decision "could mean that appellate courts are, in fact, reaching what they think is the proper conclusion regardless of the decision of the lower court." ${ }^{132}$

A similar mismatch occurs when a circuit court reviews for an abuse of discretion. The appellate court reviews the discretionary element of the lower court's decision under the typical standard, abuse of discretion, while reviewing the statutory interpretation element more deferentially than is appropriate.

It has been argued that the standard of review may be "ultimately unimportant." "133 But the mismatch has several important consequences. As an institutional matter, when a court reviews a discretionary decision de novo it divests that discretion. This divestiture is problematic because an appellate court is in a worse position to decide if the issues presented go beyond the competency of a trial court. Moreover, primary jurisdiction is fundamentally concerned with balancing federal judicial and administrative decisionmaking. ${ }^{134}$ The distinct legal and discretionary inquiries that make up primary jurisdiction are necessary components of striking the appropriate balance. The same is

128137 F3d 605 (8th Cir 1998).

129 Id at 608 ("Without deciding the standard-of-review question, which is best left to be resolved in case where it is contested, we accept the parties' invitation to review the primary jurisdiction issue de novo.").

130 Colavito v New York Organ Donor Network, Inc, 438 F3d 214, 220 (2d Cir 2006).

131 See, for example, Kumho Tire Co, Ltd v Carmichael, 526 US 137, 152 (1999) (asserting that the trial court's discretion to admit expert testimony must be reviewed for an abuse of discretion, otherwise appellate courts divest that discretion).

132 Fred Huntsman, Comment, Who Makes the Call? The Primary Jurisdiction Doctrine in Texas After Cash America International, Inc. v. Bennett, Subaru of America, Inc. v. David McDavid Nissan, Inc., and Butnaru v. Ford Motor Co., 54 Baylor L Rev 897, 924 (2002). But see id at 923-24 (suggesting that the indecision may be superficial because the Texas courts that review primary jurisdiction determinations for abuse of discretion are actually applying de novo review, indicating "that the standard of review is ultimately unimportant").

133 Id at 924.

134 See Part I.B. 
true of abstention, where courts generally avoid the standard-ofreview mismatch that exists in the primary jurisdiction context. ${ }^{135}$

When trial courts' statutory interpretations are reviewed deferentially, courts of appeals jettison their power to settle questions of law. The mismatch also breeds uncertainty because (as discussed below) circuit courts show a wide range of fidelity to their chosen standard. As a result, there may be derivative harms, such as wasting judicial resources as uncertainty increases parties' litigiousness.

In Southern Utah, the Tenth Circuit hinted at the possibility that the mismatch is mere semantics. The court was asked to review a district court's grant of primary jurisdiction. The parties disputed whether the agency had statutory authority to review the matter. ${ }^{136}$ The Tenth Circuit was bound by an earlier decision in Marshall $v E l$ Paso Natural Gas $\mathrm{Co}^{137}$ to review primary jurisdiction decisions for an abuse of discretion. ${ }^{138}$ To resolve the question of whether the BLM had authority, the Tenth Circuit had to review the district court's interpretation of the statute - a legal question. But recognizing the dilemma created by Marshall (to break with precedent or review the district court's interpretation deferentially) the court decided to "adhere to this circuit's standard of review, while noting that any error of law is presumptively an abuse of discretion and questions of law are reviewed de novo." ${ }^{139}$ Essentially, the court imported de novo review under the guise of abuse of discretion.

The Tenth Circuit's approach in Southern Utah illustrates one version of the standard-of-review mismatch that currently pervades primary jurisdiction review. The court implicitly recognized that sometimes de novo review is proper and other times abuse of discretion review is appropriate. If courts can apply the proper standard and follow precedent, however, then what standard courts claim they are applying is not of much of a concern.

The circuit split, unfortunately, is not illusory. First, the Tenth Circuit's strategy can only work in one direction. A court could not import review for abuse of discretion into de novo review. A court would have to consider, analyze, and apply its own discretion. Doing so obviates the more deferential posture of abuse of discretion review. More-

135 See Part III.B.

136 See Southern Utah, 425 F3d at 751 ("[W]e must determine whether Congress has granted the BLM authority to determine validity of R.S. 2477 rights of way in the first place."). The facts of this case are discussed more fully in Part I.B.

137874 F2d 1373 (10th Cir 1989).

138 See Southern Utah, 425 F3d at 750, citing Marshall, 874 F2d at 1377.

139 Southern Utah, $425 \mathrm{~F} 3 \mathrm{~d}$ at 750. 
over, a strategy like the one in Southern Utah is disingenuous. If pervasive, it would risk the transparency of prior decisions.

Second, and more importantly, the Tenth Circuit's approach in Southern Utah lacks analytical precision. Empirically, courts have failed to approach primary jurisdiction with nuance. They often mismatch the standard of review with one of the doctrine's elements. The D.C. Circuit, in National Telephone Cooperative Association v Exxon Mobil Corp, ${ }^{140}$ applied the abuse of discretion standard and determined that "Exxon failed to show that the [Department of Consumer and Regulatory Affairs] oversees a comprehensive regulatory scheme that in any way would be disturbed by the instant action." ${ }^{141}$ The D.C. Circuit's review was cursory at best. Its only major statement on the issue was the following: "The district court was well within its discretion." ${ }^{142}$ Whether the Department of Consumer and Regulatory Affairs oversees a regulatory scheme implicated by the lawsuit in $\mathrm{Na}$ tional Telephone Cooperative Association is a question of statutory interpretation. Questions of statutory interpretation - the first component of primary jurisdiction - are more appropriately reviewed de novo because matters of law require uniformity regardless of the specific courtroom resolving a dispute.

In the de novo camp, the Second Circuit applied true de novo review to the discretionary element of a primary jurisdiction decision. In National Communications Association, the court reversed the district court's grant of primary jurisdiction. A key issue was whether "the validity of a billing practice" for tariffs charged between telecommunications providers was a matter requiring the expertise of the FCC. ${ }^{143}$ This issue was a discretionary matter. The district court determined that the FCC's expertise was critical and granted primary jurisdiction. ${ }^{144}$ The Second Circuit disagreed. ${ }^{145}$ Under the Second Circuit's view, the issue "could easily be resolved by a district court in a reasonable amount of time." ${ }^{146}$ But under review for abuse of discretion, mere disagreement should not be enough. The court gave no weight to the district court's findings and substituted its own judgment.

The Eighth Circuit also reviewed a district court's discretionary determination de novo. In Access Telecommunications, both elements of the district court's primary jurisdiction determination were at issue.

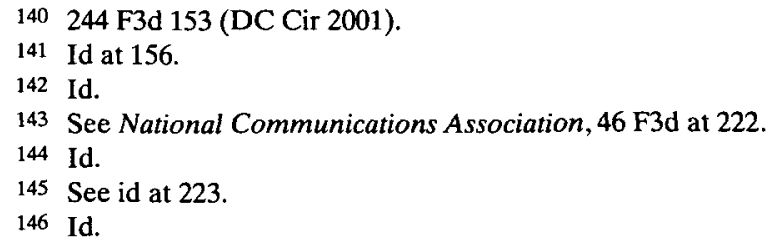


The Eighth Circuit held that the FCC had statutory authority over the dispute because "[t]he issue is whether the 6,000-foot limitation is a reasonable classification." ${ }^{147}$ More importantly, reviewing de novo, the circuit court agreed that resolving the dispute would require the decisionmaker "to become embroiled in the technical aspects of VG 7 service." ${ }^{148}$ In this case, the district court's decision held up under the least deferential standard, indicating the outcome would not have been different if the circuit court had reviewed for an abuse of discretion. That de novo review, however, was applied to both aspects of the district court's decision indicates that the standard-of-review mismatch is real. Moreover, the court noted that both parties relied on a de novo standard in their briefs. The court may have been troubled by the mismatch resulting from courts' current approach. ${ }^{149}$

More recently, and since Southern Utah, the mismatch has continued. In Ellis $v$ Tribune Television $\mathrm{Co},{ }^{150}$ the Second Circuit addressed whether a district court improperly denied the FCC primary jurisdiction regarding Tribune Television's possible violations of FCC cross-ownership rules. ${ }^{151}$ The parties conceded that the FCC had authority to address Tribune Television's possible violations. ${ }^{122}$ The dispute centered entirely on whether the district court properly applied its discretion in denying primary jurisdiction. ${ }^{153}$ The circuit court reviewed de novo. ${ }^{154}$ The district court's denial was overruled because the circuit court determined there would be a high risk of inconsistent rulings if the FCC was not allowed to address the dispute first. ${ }^{155}$ In deciding the case, the court expressly considered factors that should be left to the discretion of district courts - "whether the question at issue [wa]s within the conventional experience of judges," whether it created "a substantial danger of inconsistent rulings," and "whether a prior application to the [FCC] ha[d] been made."156

When the question of primary jurisdiction arises, it is often difficult to determine how faithful a court's opinion is to its announced standard, particularly when the announced standard is abuse of discre-

147 Access Telecommunications, 137 F3d at 609.

148 Id.

149 See id at 608.

150443 F3d 71 (2d Cir 2006).

151 See id at 73 .

152 See id at 83 n 14.

153 See id at 83 .

154 See id at $83 \times 14$.

155 See id at 92 (pointing out that inconsistent rulings in fact occurred subsequent to the district court's denial of primary jurisdiction).

156 Id at 82-83, quoting National Communications Association, 46 F3d at 222. 
tion. For example, in Wagner \& Brown v ANR Pipeline $\mathrm{Co},{ }^{157}$ the Fifth Circuit discussed why, under primary jurisdiction step two, the Federal Energy Regulatory Commission ought to have primary jurisdiction. ${ }^{1.8}$ The opinion does not discuss any of the conclusions of the district court. ${ }^{159}$ It is impossible to know whether the Fifth Circuit's disposition was as deferential as it purported to be. The court could have been improperly imposing its own discretion. This lack of transparency increases the risk that outcomes grounded on erroneous points of law will never be ameliorated.

\section{Evolution of the Circuit Split}

One commentator has described the confusion over the appropriate standard as a disagreement about whether primary jurisdiction is jurisdictional or prudential. ${ }^{160}$ This explanation is insufficient. The Supreme Court has noted that the doctrine, despite its name, is not purely jurisdictional. ${ }^{161}$ Moreover, even courts that disagree on the standard recognize the essentially prudential character of the doctrine. ${ }^{162}$

The evolution of the circuit split is complex. There is a unique story for the prevailing standard in each circuit. Although courts have rarely explained their reasons for adopting a particular standard, two themes can be discerned from the case law. ${ }^{163}$ When the interpretive element is easy and the discretionary element is the center of dispute, a court reviewing as a matter of first impression is more likely to review for abuse of discretion. When the discretionary determination is easy and the statutory interpretation is disputed, a court of appeals reviewing as a matter of first impression is more likely to review de novo.

157837 F2d 199 (5th Cir 1988).

158 See id at 203-06.

159 See id.

160 Huntsman, 54 Baylor L Rev at 899-900 (cited in note 132) (suggesting that "[i]f the doctrine were jurisdictional, then the proper standard of review would be de novo" and "if the doctrine were prudential, then the appropriate standard would be abuse of discretion").

161 See Reiter $v$ Cooper, 507 US 258, 268 (1993) (noting that primary jurisdiction is "applicable to claims properly cognizable in court that contain some issue within the special competence of an administrative agency"). See also Part I.A.2.

162 Compare Schiller v Tower Semiconductor Ltd, 449 F3d 286, 294-95 (2d Cir 2006) (applying the de novo standard and noting that "[e]ven when primary jurisdiction is not statutorily required [ ] courts may still apply the doctrine as a prudential matter"), with Southern Utah, 425 F3d at 750 (applying the abuse of discretion standard and noting that "[p]rimary jurisdiction is a prudential doctrine designed to allocate authority between courts and administrative agencies").

163 For a theoretical account of how legal rules become path dependent, see Oona A. Hathaway, Path Dependence in the Law: The Course and Pattern of Legal Change in a Common Law System, 86 Iowa L Rev 601, 622-50 (2001). 
In General Electric Co v MV Nedlloyd, ${ }^{164}$ the Second Circuit addressed whether the Federal Maritime Commission (FMC) should determine the reasonableness of a shipping rate. ${ }^{165}$ The court did not expressly adopt a standard of review, but suggested the review was de novo by referring to primary jurisdiction as a "jurisdictional issue." In General Electric, de novo review was a sensible standard because the dispute centered on the statutory interpretation element of primary jurisdiction. ${ }^{167}$ The dispositive issue was whether the type of challenge to the shipping rates was one the FMC had authority to address. ${ }^{168}$ Although the court did not declare a standard, it became the seed for de novo review in the Second Circuit. In National Communications Association, the circuit relied on General Electric in expressly declaring the standard for the first time. ${ }^{169}$

The Tenth Circuit first declared its abuse of discretion standard in Marshall. ${ }^{170}$ The standard was sensible in that case because only the discretionary component of primary jurisdiction was at issue. The dispute hinged on whether some of the factual issues within the purview of the relevant agency were "not within the conventional knowledge of judges or jurors, and will result in inconsistent orders of the district court and the [agency]." ${ }^{171}$ Since Marshall, the Tenth Circuit has continued to review for an abuse of discretion."

United States $v$ Haun $^{173}$ is also illustrative. The government appealed the district court's decision to refer the issue of whether Haun had illegally bought and sold livestock to the Department of Agriculture. The government urged de novo review because the dispositive issue was the "purely legal" question of whether the Department of

164817 F2d 1022 (2d Cir 1987).

165 See id at 1025-28 (addressing Nedlloyd's argument that under primary jurisdiction, the FMC should have reviewed GE's attack on the reasonableness of Nedlloyd's shipping rate first).

166 See id at 1025 (labeling Part I of the opinion "The Jurisdictional Issue").

167 See id at 1026-27.

168 See id (weighing the factors for primary jurisdiction and concluding that "[b]ecause those factors that bring the doctrine of primary jurisdiction into play are absent, there is no reason to adopt Nedlloyd's suggestion that the issue of the reasonableness of GE's ad valorem charge be referred to the FMC").

169 See 46 F3d at 222 (stating "the standard of review is essentially de novo" and citing General Electric for the procedure for review).

170 See 874 F2d at 1377 ("We review under an abuse of discretion standard the district court's decision whether to apply primary jurisdiction and refer this case to the [Oklahoma Corporation] Commission.").

171 Id.

172 See Southern Utah, 425 F3d at 750 ("This Court ... reviews decisions regarding primary jurisdiction under an abuse of discretion standard"), citing Marshall, 874 F2d at 1377; Brumark Corp, 57 F3d at 947-48 ("We review under an abuse of discretion standard the district court's decision whether to apply primary jurisdiction."), citing Marshall, 874 F2d at 1377.

173124 F3d 745 (6th Cir 1997). 
Agriculture had concurrent jurisdiction under the statute. ${ }^{174}$ Haun implied abuse of discretion review was appropriate because a trial court's decision to defer is discretionary. ${ }^{175}$ The court concluded de novo review was appropriate because the case boiled down to "a question of statutory interpretation, ascertaining whether a provision of the Packers and Stockyards Act confers district court jurisdiction exclusive of the agency."176

The inference that the predominating issue in a few cases has arbitrarily influenced which standard takes hold is somewhat anecdotal. The pattern, however, persists in the majority of circuits. ${ }^{17}$ Moreover, the explanation is more compelling when considered in conjunction with the cases a court turns to for guidance. When primary jurisdiction arises as an issue of first impression, circuits are influenced by two types of cases - cases involving doctrines similar to primary jurisdiction and primary jurisdiction cases from other circuits.

First, when declaring the standard of review for the first time, circuit courts have commonly looked to cases that involve doctrines similar to primary jurisdiction. In Marshall, the Tenth Circuit looked to Burford v Sun Oil Co ${ }^{178}$ and Grimes $v$ Crown Life Insurance Co, ${ }^{179}$ which applied the abuse of discretion standard to Burford abstention. ${ }^{180}$ As discussed in Part I, the key distinction between primary jurisdiction and Burford abstention is that primary jurisdiction defers to federal administrative agencies rather than state bodies. The court was insightful in looking to Burford. Interestingly, in Marshall and Grimes, it was a foregone conclusion that the requisite conditions for abstention existed. ${ }^{181}$ Grimes, therefore, only considered whether the district

174 See id at 746.

175 See id at 747.

176 Id (declaring the standard of review for the first time in the Sixth Circuit).

177 See National Telephone Cooperative Association, 244 F3d at 156 (reviewing for abuse of discretion whether a denial of primary jurisdiction would disrupt the uniformity of agency enforcement); Access Telecommunications, 137 F3d at 608-09 (accepting the parties' invitation to review de novo where the dispute was over how to define the issue in the case); Environmental Technology Council, 98 F3d at 789 (reviewing for abuse of discretion whether the agency's expertise would help resolve a constitutional issue); Newspaper Guild of Salem, 79 F3d at 1283 (reviewing de novo whether claims fell within authority of the NLRB); Puerto Rico Maritime Shipping Authority v Valley Freight Systems, Inc, 856 F2d 546, 549 (3d Cir 1988) (reviewing for abuse of discretion the district court's determination that a motion for referral to the ICC occurred too late in the litigation).

178319 US 315 (1943).

179857 F2d 699 (10th Cir 1988).

180 See Marshall, 874 F2d at 1377 (characterizing the holdings in Burford and Grimes as applying a discretionary standard of review to abstention doctrine). See also Grimes, $857 \mathrm{~F} 2 \mathrm{~d}$ at 703-04 (citing Burford as the most applicable exception to the exercise of jurisdiction).

181 See Marshall, 874 F2d at 1376-80; Grimes, 857 F2d at 703-04. 
court had abused its discretion by refusing to abstain. ${ }^{182}$ By looking to Grimes, where only the discretionary element of primary jurisdiction was at issue, the Tenth Circuit naturally adopted a holistic abuse of discretion standard and failed to recognize that primary jurisdiction entails two distinct inquiries.

Circuits that review de novo have acted similarly. The Ninth Circuit analogized primary jurisdiction to cases involving the preemption of judicial review by administrative agencies. ${ }^{133}$ When declaring its standard of review, the Sixth Circuit turned to a case discussing the exhaustion of remedies doctrine. ${ }^{184}$ Preemption and exhaustion decisions are reviewed de novo because they do not contain a discretionary element like primary jurisdiction. ${ }^{185}$ As in Marshall, the Sixth and Ninth Circuits failed to separate the elements of primary jurisdiction and, by somewhat insightful analogy, adopted a holistic standard of review.

A second pattern is that courts, without explanation, will cite to primary jurisdiction cases in other circuits. The Eighth Circuit, in Access Telecommunications, relied on the Second Circuit's adoption of de novo review in National Communications Association. ${ }^{186}$ The Fourth Circuit, in Environmental Technology Council $v$ Sierra Club, ${ }^{187}$ cited the Third Circuit's decision in In re Lower Lake Erie. ${ }^{188}$ In turn, the D.C. Circuit relied on the Fourth Circuit's standard in Environmental Technology Council. ${ }^{18}$

The most likely reason for looking to other circuit authority relates back to which element of primary jurisdiction is dispositive. In Access Telecommunications, the dispositive issue related to the statu-

182 See $857 \mathrm{~F} 2 \mathrm{~d}$ at $705-06$ (observing that "[t]he questions at issue in this case are questions of state law" and holding that the district court should have abstained because "[a]llowing the district court to exercise jurisdiction in this case would disrupt the ability of the state officers ... to devise and efficiently operate a complex system of administrative and judicial interrelationships").

183 See International Brotherhood of Teamsters, 50 F3d at 773, citing Milne Employees Association v Sun Carriers, Inc, 960 F2d 1401, 1406 (9th Cir 1991) (addressing preemption of federal jurisdiction).

184 See Haun, 124 F3d at 747, citing Holmes Financial Associates, Inc v Resolution Trust Corp, 33 F3d 561, 562-63 (6th Cir 1994) ("The issue presented is whether ... federal courts have exclusive jurisdiction over suits ... [first] filed in state court.").

185 See Western Pacific Railroad, 352 US at 63 (comparing exhaustion to primary jurisdiction); Shane v Greyhound Lines, Inc, 868 F2d 1057, 1059-61 (9th Cir 1989) (discussing federal preemption of state law claims). See also Currie, Federal Courts at 503 n 3 (cited in note 8) (comparing exhaustion to primary jurisdiction); Part I.A.2.

186 See Access Telecommunications, 137 F3d at 608 (reviewing de novo after both parties used that standard in their briefs by citing to National Communications Association).

18798 F3d 774 (4th Cir 1996).

188 See id at 789.

189 See National Telephone Cooperative Association, 244 F3d at 156. Note that the D.C. Circuit suggested the standard was abuse of discretion in United States $v$ Bessemer and Lake Erie Railroad Co, 717 F2d 593, 599 (DC Cir 1983), but did not formally adopt the standard until $\mathrm{Na}$ tional Telephone Cooperative Association (which never mentions Bessemer). 
tory interpretation element. ${ }^{100}$ It makes sense that the Eighth Circuit would cite established authority for the proposition that de novo review is appropriate. Moreover, a court is likely to find another circuit's standard persuasive when it buttresses the sitting court's intuitions about the appropriate standard. In Environmental Technology Council and National Telephone Cooperative Association, the discretionary element of primary jurisdiction was the dispositive consideration. ${ }^{191}$ It similarly makes sense that the Fourth and D.C. Circuits would rely on established authority for an abuse of discretion standard.

Courts have consequently developed case law that fortifies improperly holistic standards for reviewing primary jurisdiction. Instead of recognizing the two distinct components of primary jurisdiction and using that distinction to distinguish prior cases, circuits adhere to these ill-considered precedents. Confusion and disagreement have developed as courts continue to review various permutations of the primary jurisdiction question.

\section{THE PROPER FRAMEWORK FOR APPELLATE REVIEW OF PRIMARY JURISDICTION DETERMINATIONS}

Courts of appeals should review primary jurisdiction determinations in a two-tiered manner. This approach has been applied in several substantive areas of law where district courts make determinations that include distinct legal and discretionary components. Significantly, a two-step review is applied to other discretionary abstention doctrines. This Part outlines the proper two-step review for primary jurisdiction and compares that approach to appellate review of other doctrines of abstention.

\section{A. A New Approach: The Primary Jurisdiction Two-Step}

Because a primary jurisdiction decision involves interpretative and discretionary elements, it has been suggested "it would make little sense to do part of the analysis under de novo review and another part under abuse of discretion review." ${ }^{192}$ That suggestion is wrong. Circuit courts can, and do, distinguish between legal elements and discretionary elements composing part of a larger doctrinal decision tree.

190 See 137 F3d at 608-09.

191 See Environmental Technology Council, 98 F3d at 789 (reviewing for abuse of discretion whether the agency's expertise would help resolve a constitutional issue); National Telephone Cooperative Association, 244 F3d at 156 (reviewing for abuse of discretion whether a denial of primary jurisdiction would disrupt uniformity).

192 Huntsman, 54 Baylor L Rev at 923 (cited in note 132). 
Circuit courts ought to break a primary jurisdiction decision into its two elements: statutory interpretation and judicial discretion. Then they ought to review those distinct elements separately under different standards. Under this two-step review, a district court's statutory interpretation-a matter of law-is reviewed de novo. A district court's decision as to whether the purposes behind primary jurisdiction are furthered by deferring to the agency-a matter of discretion -is reviewed for an abuse of discretion.

If an agency does not oversee a regulatory scheme implicated by the dispute, then that is the end of the matter because primary jurisdiction is never appropriate in such a situation. For example, in National Telephone Cooperative Association, the court should have reviewed de novo whether "the [Department of Consumer and Regulatory Affairs] oversees a comprehensive regulatory scheme that in any way would be disturbed by the instant action." ${ }^{193}$ Instead, the circuit court applied a cursory review of the lower court's statutory interpretation. ${ }^{104}$

On the other hand, if the reviewing court determines that an agency does have the authority to address the issues implicated by the litigation, then the circuit court should review the lower court's exercise of discretion in granting or rejecting primary jurisdiction for an abuse of discretion. For example, in National Communications Association, the Second Circuit should have reviewed the district court's decision to refer certain issues to the FCC deferentially. ${ }^{195}$ Instead, the court reversed the district court's grant based on a de novo standard of review. ${ }^{196}$ Finally, when reviewing the discretionary element of primary jurisdiction, circuit courts should continue to look for guidance to the factors considered in Western Pacific Railroad. ${ }^{197}$

It is important that step two is reviewed for abuse of discretion. Step two requires a district court to consider factors such as the potential consequences of further delay, the importance of technical issues to an ultimate resolution, and whether the question over which the court and agency share jurisdiction is one beyond the competence of a judge. ${ }^{198}$ These considerations embroil a district judge in the facts in a way that appellate judges cannot replicate. Allowing a circuit court to substitute its discretion on such matters is inconsonant with primary

193244 F3d at 156.

194 See id.

195 See 46 F3d at 222.

196 See id at 222-25 (explaining its reasons for reversing the distraction court without indicating any deference to the district court's determination).

197 See 352 US at 64 (discussing "the desirable uniformity which would obtain if initially a specialized agency passed on certain types of administrative questions" and "the expert and specialized knowledge" of an agency assisted in adjudication).

198 See Part I.A. 
jurisdiction's central theme of deferring to a more appropriate decisionmaker.

\section{B. The Workability of a Two-Step Standard of Review}

The two-step standard of review proposed by this Comment is novel only as applied to primary jurisdiction. Two-step review is applied to many determinations which involve legal and discretionary considerations. For example, courts often apply a two-step review to criminal sentencing. In United States $v$ Myers, ${ }^{199}$ the court "first examine[d] de novo whether the district court correctly interpreted and applied the [sentencing] guidelines." ${ }^{200}$ The court then reviewed sentences outside the guidelines range for abuse of discretion. ${ }^{201}$ Courts also review a decision on whether to bar an expert witness in a twotiered fashion. The Seventh Circuit, in Durkin v Equifax Check Services, $\operatorname{Inc}{ }^{202}$ stated that "[w]e first review, de novo, whether the district court properly followed the framework set forth in Daubert... Having determined that the district court properly applied Daubert, we next review the district court's decision to bar an expert for an abuse of discretion." 203

Most importantly, courts of appeals have already applied twotiered review to other two-step abstention doctrines that involve a predicate legal inquiry followed by a discretionary determination. Pullman abstention - suspending proceedings to allow unsettled state law to eliminate or narrow constitutional issues in federal courtrequires a two-step inquiry. A court must first decide whether uncertain state law underlies a constitutional question facing the court and whether the uncertainty is amenable to resolution in state court such that it mitigates or eliminates the need to resolve the constitutional question. ${ }^{24}$ If the conditions allowing for abstention exist, a court must exercise its discretion to decide if suspending federal court proceedings is appropriate in the particular case. ${ }^{205}$ In line with this Comment's proposal, the Third Circuit applies "two separate standards of review. ${ }^{206}$ The first step is reviewed de novo. ${ }^{207}$ If a district court properly

199439 F3d 415 (8th Cir 2006).

200 Id at 417 (quotation marks omitted).

201 See id.

202406 F3d 410 (7th Cir 2005).

203 Id at 420 (quotation marks omitted).

204 See Railroad Commission of Texas v Pullman Co, 312 US 496, 498-500 (1941); Chez Sez III Corp v Township of Union, 945 F2d 628, 631 (3d Cir 1991).

205 See Chez Sez, 945 F2d at 631 (observing that "[i]f the district court finds that all three of the 'special circumstances' are present, it must then make a discretionary determination as to whether abstention is in fact appropriate under the circumstances of the particular case").

206 Id. 
concludes that the requirements for abstention are met, then "the [] question is whether the trial judge abused his discretion in ... deciding to invoke the Pullman doctrine."

Courts of appeals that have explicitly addressed the standard-ofreview question under Pullman agree on the two-step approach. The Fifth Circuit declared, "[d]espite the confusion that once existed," it would "apply a two-tiered standard of review in abstention cases." The Ninth Circuit used the same two-step approach in what it labels a "modified abuse of discretion" review. ${ }^{20}$ The Ninth Circuit reviews "de novo whether the requirements for Pullman abstention have been met" and the "district court's ultimate decision to abstain ... for abuse of discretion." 211

Burford abstention-deferring to complex state administrative procedures-also requires a district court to first ask whether the requirements for abstention exist. ${ }^{212}$ If a court finds abstention is possible, it must decide whether it is appropriate. ${ }^{213}$ The Ninth Circuit reviews Burford decisions in precisely the manner this Comment recommends for primary jurisdiction. The Circuit "review[s] de novo whether the requirements for abstention have been met." ${ }^{144}$ When the requirements for abstention are present, the Ninth Circuit "review[s] the district court's decision to abstain for an abuse of discretion." 215

Some circuits diverge from this approach when reviewing Burford decisions. ${ }^{216}$ But most circuits that do not explicitly apply a twotier standard of review recognize that review should be "rigorous," and "there is little or no discretion to abstain in a case which does not meet traditional abstention requirements." ${ }^{217}$

207 Id.

208 Id.

209 Nationwide Mutual Insurance Co v Unauthorized Practice of Law Committee, 283 F3d 650,652 (5th Cir 2002).

210 Smelt $v$ County of Orange, 447 F3d 673, 678 (9th Cir 2006).

211 Id.

212 See City of Tucson v U.S. West Communications, Inc, 284 F3d 1128, 1132-33 (9th Cir 2002) (discussing the requirements for abstention).

213 See Burford, 319 US at 318 (discussing when abstention would be appropriate); U.S. West Communications, $284 \mathrm{~F} 3 \mathrm{~d}$ at 1133 (same).

214 U.S. West Communications, 284 F3d at 1132.

215 Id.

216 See, for example, Habich v City of Dearborn, 331 F3d 524, 530 n 2 (6th Cir 2003) (reviewing decisions to abstain under Burford de novo); First Penn-Pacific Life Insurance Co $v$ Evans, 304 F3d 345, 348 (4th Cir 2002) (reviewing decisions to abstain under Burford only for abuse of discretion).

217 Bethphage Lutheran Service, Inc v Weicker, 965 F2d 1239, 1244-45 (2d Cir 1992), citing Mobil Oil Corp v City of Long Beach, 772 F2d 534, 540 (9th Cir 1985). See also Wilson v Valley Electric Membership Corp, 8 F3d 311, 313 (5th Cir 1993) (recognizing that "the allowable discretion is quite narrow, because it must be exercised within the narrow and specific limits prescribed by the particular abstention doctrine involved") (quotation marks omitted). 
The other discretionary abstention doctrine is Colorado Riversuspending proceedings in favor of concurrent state proceedings. Although this form of abstention is much narrower, ${ }^{218}$ the first question for a district court is whether the "exceptional circumstances" for applying the doctrine exist. ${ }^{219}$ If the exceptional circumstances exist, a district court must decide whether abstention is appropriate for the case at hand. ${ }^{20}$ The Fifth, Seventh, and Ninth Circuits agree that twostep review is appropriate. ${ }^{221}$ All three circuits review the threshold legal decision de novo. ${ }^{22}$ The district court's discretionary decision whether to abstain is reviewed for abuse of discretion. ${ }^{22}$

Younger and Thibodaux abstention, in contrast to other abstention doctrines, are "absolute." ${ }^{224}$ Abstention under both requires a single legal inquiry. Accordingly, most circuits have settled on a purely de novo standard for "the essentially legal determination of whether the requirements for abstention have been met." ${ }^{, 25}$ This level of review is appropriate because there is no discretionary component to the district court's overall conclusion. This practice buttresses the notion that the standard of review should reflect the character of the underlying analysis.

218 See Moses $H$ Cone Memorial Hospital v Mercury Construction Corp, 460 US 1, 14-15 (1983) (describing this doctrine of abstention as an "extraordinary and narrow exception" to the general rule that district courts must adjudicate cases properly before them).

219 Rosser $v$ Chrysler Corp, 864 F2d 1299, 1306 (7th Cir 1988).

220 See id ("[W]hen the proper exceptional circumstances exist, a federal court can abstain from exercising its jurisdiction and defer to the concurrent jurisdiction of a state court when there is a parallel state court action pending."). See also Holder v Holder, 305 F3d 854, 863 (9th Cir 2002); United States Fidelity \& Guaranty Co v Murphy Oil USA, Inc, 21 F3d 259, 261-62 (8th Cir 1994); Arizona v San Carlos Apache Tribe of Arizona, 463 US 545, 569 (1983).

221 See, for example, Smelt, 447 F3d at 678 (9th Cir); Nationwide Mutual, 283 F3d at 652 (5th Cir); Rosser, 864 F2d at 1307 (7th Cir).

222 See Smelt, 447 F3d at 678 (9th Cir); Bank One, NA v Boyd, 288 F3d 181, 183-84 (5th Cir 2002); Nationwide Mutual, 283 F3d at 652 (5th Cir); Rosser, 864 F2d at 1307 (7th Cir).

223 See Smelt, 447 F3d at 678 (9th Cir); Bank One, 288 F3d at 184 (5th Cir); Nationwide Mutual, 283 F3d at 652 (5th Cir); Rosser, 864 F2d at 1307 (7th Cir).

224 Trust and Investment Advisers, Inc v Hogsett, 43 F3d 290, 294 (7th Cir 1994).

225 Brooks v New Hampshire Supreme Court, 80 F3d 633, 637 (1st Cir 1996). See, for example, Superior Beverage Co, Inc v Schieffelin \& Co, 448 F3d 910, 913 (6th Cir 2006) (Thibodaux abstention); Diamond " $D$ " Construction Corp v McGowan, 282 F3d 191, 197 (2d Cir 2002) (Younger abstention); Taylor v Jaquez, 126 F3d 1294, 1296 (10th Cir 1997) (Younger abstention); Arkebauer v Kiley, 985 F2d 1351, 1357 (7th Cir 1993) (Younger abstention); Mission Oaks Mobile Home Park $v$ City of Hollister, 989 F2d 359, 360 (9th Cir 1993) (Younger abstention). Some circuits have applied the abuse of discretion standard when addressing Younger abstention. See, for example, Wexler v Lepore, 385 F3d 1336, 1338 (11th Cir 2004). Others have applied a two-tiered approach similar to that urged here. See, for example, Yang $v$ Tsui, 416 F3d 199, 201 (3d Cir 2005); Texas Association of Business $v$ Earle, 388 F3d 515, 518 (5th Cir 2004), citing Nationwide Mutual, 283 F3d at 652. These cases highlight "the elusiveness of the standard often applied to review Younger abstention." Taylor, 126 F3d at 1296. In reality, they illustrate that circuits sometimes conflate the various types of abstention. The proper approach, in contrast to primary jurisdiction, should be pure de novo review because "when a case meets the Younger criteria, there is no discretion for the district court to exercise." Id, quoting Hogsett, 43 F3d at 294. 


\section{CONCLUSION}

Applying a single standard of review to a district court's primary jurisdiction determination creates a mismatch between the chosen standard and one of the two elements involved in making such determinations. An unfortunate byproduct of the common law system, until now, has been courts' failure to realize that a two-step standard, often applied in other contexts, would resolve the confusion and disagreement among the circuit courts. Going forward, the federal courts of appeals should avoid the improperly holistic approaches which currently prevail. Reviewing courts should adopt a two-step review that parallels the two-step determination implicit in every grant or denial of primary jurisdiction. 